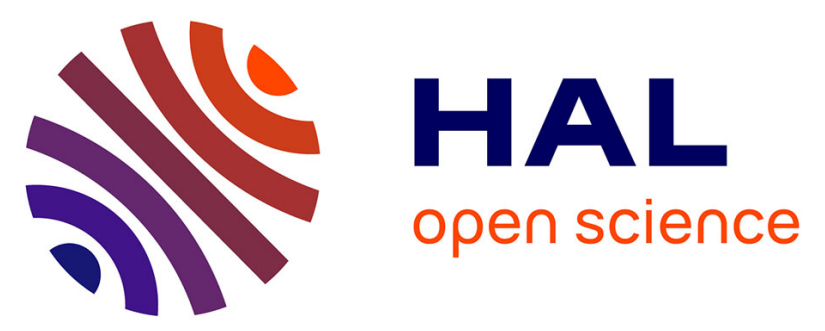

\title{
Estimation of the Iberian lynx () population in the Doñana area, SW Spain, using capture-recapture analysis of camera-trapping data
}

German Garrote, Ramon Perez de Ayala, Pablo Pereira, Francisco Robles, Nicolas Guzman, Francisco J. García, Maria C. Iglesias, Jaime Hervás, Iñigo

Fajardo, Manuel Simón, et al.

\section{To cite this version:}

German Garrote, Ramon Perez de Ayala, Pablo Pereira, Francisco Robles, Nicolas Guzman, et al.. Estimation of the Iberian lynx () population in the Doñana area, SW Spain, using capture-recapture analysis of camera-trapping data. European Journal of Wildlife Research, 2010, 57 (2), pp.355-362. 10.1007/s10344-010-0440-7 . hal-00629072

\section{HAL Id: hal-00629072 https://hal.science/hal-00629072}

Submitted on 5 Oct 2011

HAL is a multi-disciplinary open access archive for the deposit and dissemination of scientific research documents, whether they are published or not. The documents may come from teaching and research institutions in France or abroad, or from public or private research centers.
L'archive ouverte pluridisciplinaire HAL, est destinée au dépôt et à la diffusion de documents scientifiques de niveau recherche, publiés ou non, émanant des établissements d'enseignement et de recherche français ou étrangers, des laboratoires publics ou privés. 


\title{
Estimation of the Iberian lynx (Lynx pardinus) population in the Doñana area, SW Spain, using capture-recapture analysis of camera-trapping data
}

\author{
German Garrote - Ramon Perez de Ayala • Pablo Pereira - Francisco Robles • \\ Nicolas Guzman • Francisco J. García • Maria C. Iglesias • Jaime Hervás • \\ Iñigo Fajardo • Manuel Simón • Jose L. Barroso
}

Received: 17 August 2009/Revised: 21 July 2010/Accepted: 14 August 2010 /Published online: 5 October 2010

(C) Springer-Verlag 2010

\begin{abstract}
The Iberian lynx (Lynx pardinus) has a highly restricted geographic distribution, limited even within the Iberian Peninsula. The last national survey reported less than 200 remaining individuals, distributed in two isolated areasAndújar-Cardeña and Doñana-and in consequence, the Iberian lynx was listed by the International Union for Conservation of Nature as "Critically Endangered". In this study, we estimate the Iberian lynx population size in the Doñana area using capture-recapture analysis of cameratrapping data. A model with different capture probability for
\end{abstract}

Communicated by C. Gortázar

G. Garrote $(\bowtie) \cdot$ R. Perez de Ayala $\cdot$ N. Guzman · F. J. García $\cdot$

M. C. Iglesias · J. Hervás

Dirección General para la Biodiversidad,

Ministerio de Medio Ambiente,

Madrid, Spain

e-mail: germang@wocplanet.com

P. Pereira $\cdot$ F. Robles

Parque Nacional de Doñana,

Organismo Autónomo de Parques Nacionales, MIMAM,

Andalusia, Spain

\section{Fajardo}

Delegación Provincial de Huelva,

Consejería de Medio Ambiente, Junta de Andalucía,

Huelva, Spain

\section{Simón · J. L. Barroso}

Parque Natural de Doñana, Consejería de Medio Ambiente, Junta de Andalucía,

Andalusia, Spain

\section{Present Address:}

G. Garrote

Vertebrate Biology and Conservation UCM Research Group, Faculty of Biology, Complutense University of Madrid, Madrid, Spain each individual $\left(\mathrm{M}_{\mathrm{h}}\right)$ yielded an estimate of 26 Iberian lynxes $(\mathrm{SE}=5.26)$ more than 1 year old. It is considered that a small slant in the estimation of the number of individuals could exist due to the presence of dispersers inside the study area that were not detected. Our study shows: (1) a reduction in number since the 1980s (45 individuals), and falling below the theoretical threshold of genetic viability, (2) changes in the species' spatial distribution in this area, and (3) as for other carnivore species, photographic capture-recapture methods are applicable for estimating the size of Iberian lynx populations

Keywords Lynx pardinus · Iberian lynx · Camera trapping · Capture-recapture $\cdot$ Population estimates $\cdot$ Doñana

\section{Introduction}

Ineffective carnivore survey methods limit the ability of managers and researchers to make appropriate research conclusions and management recommendations (Heilbrun et al. 2006). A technique that estimates density (Lancia et al. 1994), detects changes over time (Gibbs 2000), and considers the welfare of individual animals (Gibbs 2000; Murray and Fuller 2000; Peterson et al. 2003) would greatly enhance the ability to monitor and manage populations.

The use of camera traps to detect elusive mammals, such as carnivores, has proven to be highly efficient (Cutler and Swann 1999), and some recent studies have proven the great potential that this method can provide for estimating population sizes of secretive, but individually recognisable animals. Populations of tiger (Panthera tigris; Karanth and Nichols 1998), leopard (Panthera pardus; Henschel and 
Ray 2003), snow leopard (Uncia uncia; Jackson et al. 2006), and ocelot (Felis pardalis; Trolle and Kéry 2003) have been successfully estimated using capture-recapture analysis of camera-trapping data.

The Iberian lynx (Lynx pardinus) population, limited both to and within the Iberian Peninsula (Mitchell-Jones et al. 1999), has declined markedly over the last century (Graells 1897; Cabrera 1914; Valverde 1963). During the late 1980s, a national survey estimated a total population size of only approximately 1,000 adult individuals (Rodríguez and Delibes 1992). This situation was mainly due to wide-scale vegetation removal and transformation, human-caused mortality, and the decline of its main prey, the wild rabbit (Oryctolagus cuniculus), due to the impact of the myxomatosis virus (Rodríguez and Delibes 1992, 2003). During the late 1980 s, the Iberian rabbit populations were also seriously affected by rabbit hemorrhagic disease (RHD; Villafuerte et al. 1994), and this could have affected lynx populations via the severe decline of its specialised prey. Indeed, a national survey carried out in 2002 (Guzmán et al. 2004) reported an absolute number of less than 160 individual Iberian lynxes for the whole of Spain, distributed in just two isolated areas: Andújar-Cardeña and Doñana. In consequence, the species was listed by the International Union for Conservation of Nature (IUCN) as "Critically Endangered" (IUCN 2002, 2007). This has led to the implementation of several management measures which aim to stabilise the population and in the future, try to reverse this situation (see Simón 2008).

Population estimates in the Doñana area showed that the number of individuals also declined (Rau et al. 1985; Palomares et al. 1991; Ferreras 2001; Guzman et al. 2004) as in the rest of its distribution range and for the same factors mentioned above.

Previous censuses in the Doñana area were based on intensive searches for signs of lynx presence (tracks and droppings) in order to estimate the population (Palomares et al. 1991; Guzman et al. 2004). The authors assumed a direct relationship between the index of signs abundance and lynx numbers. Palomares et al. (1991) estimated there were 45 (40-50) individuals (excluding cubs still tended by their mother) in the Doñana area in the late 1980s, while Guzmán et al. (2004) estimated 36-42 lynxes there in 2002.

These methods provided a good approximation of the population size. However, considering that the Iberian lynx is the most endangered feline in the world, it is necessary to obtain as rigorous and accurate estimates as are possible, with methods capable of quickly detecting population changes and thus allowing the adoption of emergency management measures when required.

The aim of the present study was to determine whether the use of camera-trapping techniques is applicable to the Iberian lynx, a species with a very limited population and restricted distribution area, as well as whether this method can also be applied to estimate its population using capture-recapture analysis.

These conclusions are crucial for establishing an adequate monitoring programme which will allow the design and adoption of further conservation measures.

\section{Materials and methods}

Study area

The study area is located in SW Spain, including Doñana National Park, Doñana Natural Park, and the peripheral zone (Fig. 1). The area is bordered on the south and west by the Atlantic Ocean, to the east by the Guadalquivir River, and to the north by the alluvial plain of the River Tinto and the intensively cultivated high ground of Aljarafe (Anon 1989).

The area is generally flat, but with some undulations in the north, and the eastern third is largely seasonally flooded marshland. The climate is sub-humid Mediterranean with mild, wet winters and hot, dry summers and the annual rainfall is between 500 and $1,000 \mathrm{~mm}$ (Rivas-Martínez 1987).

Seven vegetation units can be distinguished: Mediterranean scrub, Eucalyptus spp. plantations, pine plantations, forested pastureland, marsh, beaches and dunes, and cultivated land. Outside the protected areas, irrigated agriculture and coastal tourism have developed to a large degree over the last two decades, with a corresponding considerable increase in human impact.

In most of the National Park, human access is restricted to researchers and wardens, and hunting is strictly forbidden. Conversely, outside the National Park boundaries, levels of human access depend on land owners and game hunting is frequent.

\section{Camera trapping}

The fieldwork was undertaken between November 2002 and February 2003 by four teams of two to four people each. Photographs were taken using $35 \mathrm{~mm}$ cameras with a data register and automatic flash. The cameras were modified to allow activation via an external $25 \times 25 \mathrm{~cm}$ pressure plate, positioned $170 \mathrm{~cm}$ away, and triggered when stepped on by an animal. Lynx urine obtained from captive animals was used as the lure, and placed on an inert support $50 \mathrm{~cm}$ above the ground and adjacent to the pressure plate. This attractant was replaced every 3 days $(2.5 \mathrm{ml} / \mathrm{visit})$ according to previous studies about the efficiency of this lure in attracting lynxes (Garrote et al. 2001). Attractants are often deployed by researchers at camera-trap sites to 


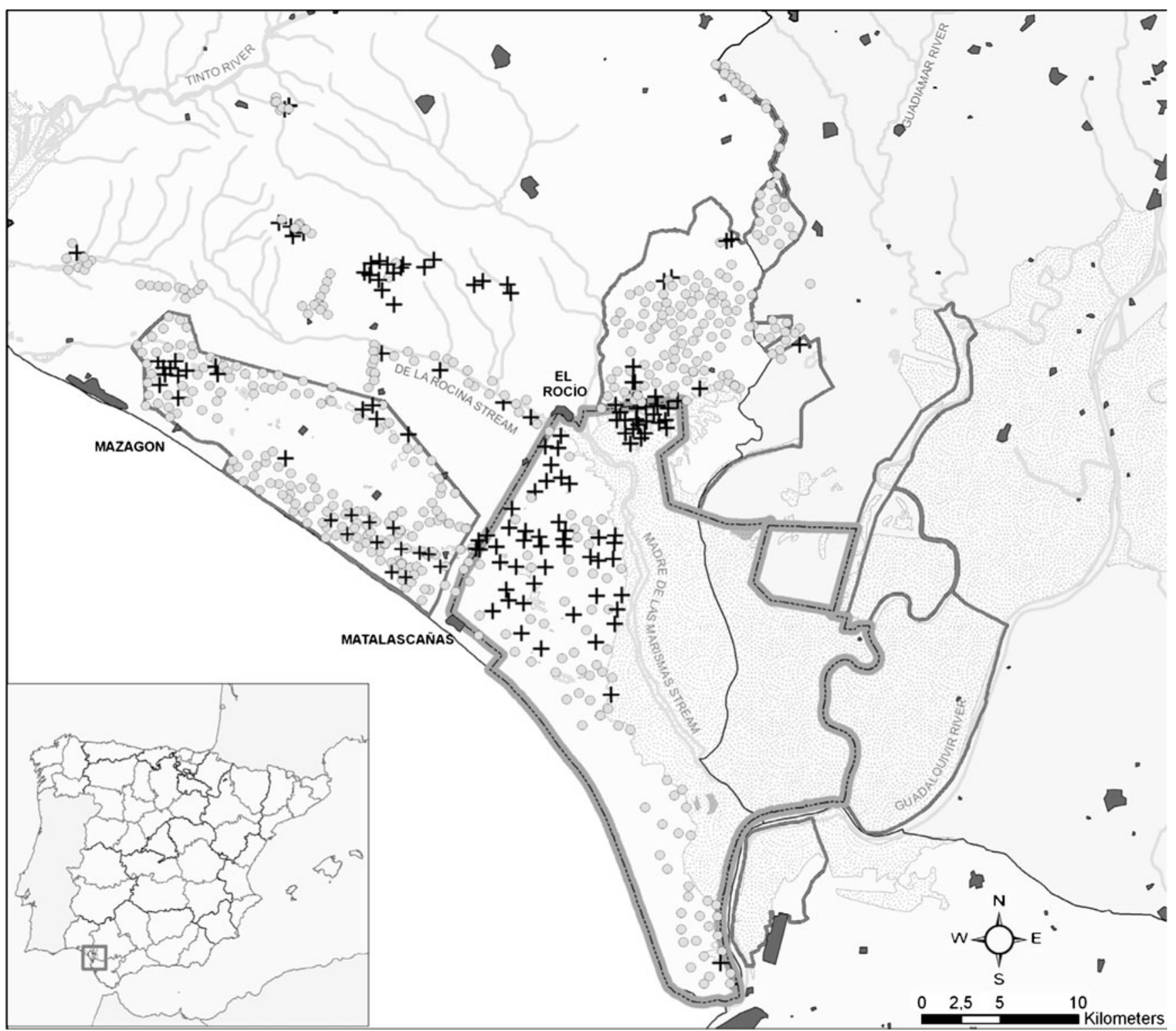

Fig. 1 Survey area in Doñana National Park (broken line), Doñana Natural Park (continuous line), and peripheral area showing camera trap layout (grey dot). Camera trap with Iberian lynx photograph (plus sign)

encourage visits by carnivores (Trolle and Kéry 2003; Zielinski and Kucera 1995). As long as the effort and baiting pattern/protocol is standardised, the use of such attractants does not have any major sampling implications and poses no statistical problem for capture-recapture estimates (Henschel and Ray 2003, and see Trolle and Kéry 2003).

The entire area potentially used by Iberian lynx was surveyed inside both the National and Natural Park boundaries (Fig. 1), covering all but the marsh, beach, dunes, cultivated land, and pastures. In the peripheral areas, the cameras were placed at those sites where signs had been detected within the previous year (scats, tracks, road casualties). The main areas inside the National Park not included in this study were marshlands; inside the western Natural Park, the areas excluded were temporary pools (the Abalario lagoons) containing water during our study. Neither of these habitats was used by lynx within both the National and Natural Parks.

The distance between camera traps was $400-800 \mathrm{~m}$, producing a density of $>4$ traps per 450 ha, the smallest occupied home range size known for any given age-sex class (an adult female lynx breeding in a high rabbit density situation; Ferreras et al. 1997; Palomares et al. 2001). Consequently, individuals of other age-sex classes will be exposed to a greater number of traps (Otis et al. 1978; Karanth and Nichols 2002). In order to obtain an adequate number of lynx captures, the camera-trap locations were 
chosen to maximise capture probabilities (Karanth and Nichols 1998). Each camera remained continuously active during the entire survey period for each block (see "Statistical methods" section).

All lynxes photographed were individually identified through a comparison of distinguishing natural body marking (spots), as made in other species such as tigers, leopards, and ocelots (Karanth and Nichols 1998; Henschel and Ray 2003; Trolle and Kéry 2003).

\section{Statistical methods}

The study area was divided into two blocks (east and west) which were sampled sequentially (with a 10-day gap between them to allow for camera relocation) for the same total time period ( $N=30$ days). Capture histories were developed for each lynx older than a year identified by the camera trapping. Cubs were not included in the analysis because they could have lower capture probabilities (Karanth and Nichols 1998). The capture history consisted of a string of ones and zeros indicating whether the individual was camera trapped (1) or not (0) during each "trapping occasion". The capture history data of the first sampling day, in each of the two blocks were combined to form one sampling occasion (Karanth and Nichols 2002; Soisalo and Cavalcanti 2006). The same procedure was used for each of the remaining days within the 30-day sampling period.

The capture histories data were analysed using the MARK software (White and Burnham 1999), developed to implement closed-population capture-recapture models. The MARK programme produces abundance estimates from seven models that differ in their assumptions about capture probability. Individual heterogeneity, behavioural response, and time are used as the sources of variation in the capture probabilities.

Model $\mathrm{M}_{0}$, assumes a constant capture probability across all occasions and animals. Model $\mathrm{M}_{\mathrm{t}}$ (time) assumes that capture probability varies between occasions. Model $\mathrm{M}_{\mathrm{b}}$ (behaviour) assumes that capture probability differs for animals that have, or have not been captured previously. Model $\mathrm{M}_{\mathrm{h}}$ (heterogeneity) assumes that each animal had its own probability of being captured. In addition, MARK allows estimation under four models that are pairwise combinations of these sources of variation in capture probability (Models $\mathrm{M}_{\mathrm{bh}}, \mathrm{M}_{\mathrm{th}}, \mathrm{M}_{\mathrm{tb}}, \mathrm{M}_{\mathrm{tbh}}$ ).

To identify an adequate model for estimation, we used the goodness-of-fit test, between-model test, and the model selection algorithm (Otis et al. 1978; Rexstad and Burnham 1991) provided in MARK.

These models are designed for closed populations, so assume no changes during the study. To ensure that our population was closed, the best approach was to make the period of study as short as possible (Otis et al. 1978). Thus, we only use the first 30 days from each phase of camera trapping for the analysis, and the total survey period was consequently 70 days. This was a short trapping period to assume that the population stayed stable over the study period (Karanth and Nichols 1998; Trolle and Kéry 2003; Silver et al. 2004).

The area sampled, and the area occupied by lynx was defined by an outer buffer strip equal to the one-half of the mean maximum distance Iberian lynx travelled between camera-trap stations placed and between camera trap stations with Iberian lynx photograph, respectively (Karanth and Nichols 2002).

\section{Results}

During the study period, 543 trapping stations were installed for 30 days each, 280 in the east block and 263 in the west block. The total camera-trapping effort leads to 16,290 camera-trapping nights. Twenty different Iberian lynx (nine males and 11 females) were photographed a total of 129 times at 116 different camera stations. Some individuals were recaptured multiple times and at multiple camera stations within one survey day. Because closedpopulation capture-recapture models consider only one recapture per "trapping occasion", a total of 87 positive trapping occasions were considered for the total of 129 captures (Table 1).

The number of trapping occasions for each individual varied from 1 to 19 (Table 1), indicating a notable individual variation in capture probability. Except for one female, all of those captured had been photographed previously in earlier surveys undertaken since 1999, helping the task of ageing and sexing each.

The cumulative curve of individuals "captured" during the survey stabilised after 20 days (Fig. 2). This signifies that no new individuals were photographed after day 20 . Given this information, we deduce that the length of the survey was adequate for the aims of our study.

The resulting population size estimate was 26 Iberian lynx $(\mathrm{SE}=5.26)$ more than 1 year old. The model selection algorithm in MARK selected the model $\mathrm{M}_{\mathrm{h}}$, with a different capture probability for each individual. The estimated capture probability per occasion and individual was 0.1115 , and the estimated probability of catching a lynx at least once during the entire study period is given by the ratio of total number of animals caught to the estimated population size, $20 / 26=0.77$ (Karanth and Nichols 1998).

To test for a possible differential effect of the attractant on the two sexes or on different age classes which could bias the final estimates, the population estimates were made separately for males and females, and for adult and non- 
Table 1 Summary of camera-trapping results

\begin{tabular}{|c|c|c|c|}
\hline Individual & Trapping occasions & Age & Sex \\
\hline IL01 & 1 & Adult & Female \\
\hline IL02 & 5 & Adult & Female \\
\hline IL03 & 5 & Adult & Female \\
\hline IL04 & 1 & Adult & Female \\
\hline IL05 & 3 & Adult & Female \\
\hline IL06 & 1 & Adult & Female \\
\hline IL07 & 1 & Adult & Female \\
\hline IL08 & 1 & Adult & Male \\
\hline IL09 & 3 & Adult & Male \\
\hline IL10 & 1 & Adult & Male \\
\hline IL11 & 1 & Adult & Male \\
\hline IL12 & 5 & Adult & Male \\
\hline IL13 & 19 & Indet. & Female \\
\hline IL14 & 2 & $<3$ years & Female \\
\hline IL15 & 1 & $<3$ years & Male \\
\hline IL16 & 15 & $<2$ years & Female \\
\hline IL17 & 12 & $<2$ years & Female \\
\hline IL18 & 7 & $<2$ years & Female \\
\hline IL19 & 2 & $<2$ years & Male \\
\hline IL20 & 1 & $<2$ years & Male \\
\hline
\end{tabular}

Number of trapping occasions, age, and sex of each individual photographed

adult lynxes. Following the recommendations of Karanth and Nichols (2002) the $\mathrm{M}_{\mathrm{h}}$ was used since this most probably better reflects the behaviours of solitary cats, and would provide a reasonable model for lynx capture probability (Kelly et al. 2008). This makes biological sense since most cats exhibit some degree of territoriality, with home range size and trap access varying and depending on the individual's social position and spatial location in the landscape (Henschel and Ray 2003; Karanth and Nichols 1998, 2002; Silver et al. 2004). In addition to expecting

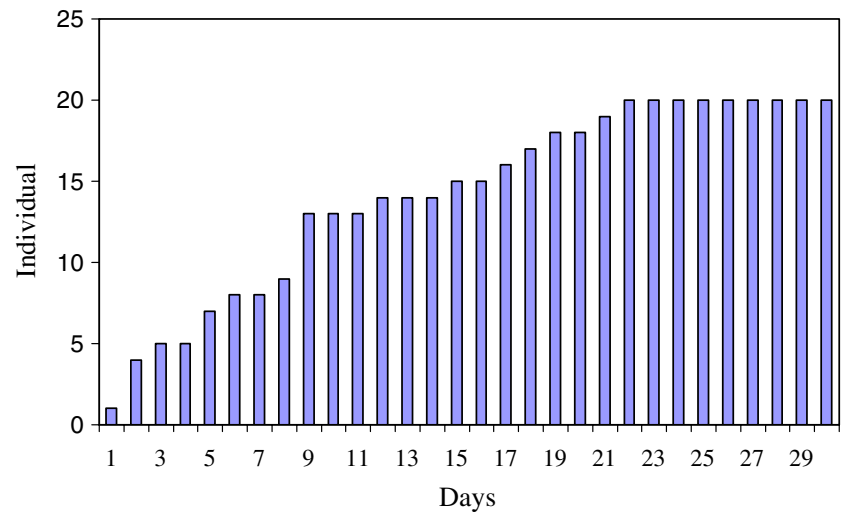

Fig. 2 Cumulative curve for photo-identified Iberian lynx. Days from the start of camera-trapping ( $x$-axis) versus photo-identified individuals ( $y$-axis) heterogeneity of capture probabilities, the use of $\mathrm{M}_{\mathrm{h}}$ is preferable, because the jackknife estimator (Burnham and Overton 1979) for this model is robust to deviations from underlying model assumptions, and has performed well in simulation studies (Otis et al. 1978; Burnham and Overton 1979).

The population estimates obtained for lynx more than 1 year old were 14 females (SE: 2.5697) and 12 (SE: 3.5136) males. The sum of both estimates coincides with that obtained from the combined matrix of males and females.

The population estimates obtained for adult lynxes ( $\geq 3$ years) were 15 individuals (SE: 3.513), and ten individuals (SE: 2.053) for non-adults ( $<3$ years). The sum of both estimates is only one lynx less than the estimate obtained from the combined matrix.

The mean maximum distances moved by individual Iberian lynx between successive captures were $2.04 \mathrm{~km}$, providing an outer buffer-strip width of $1.02 \mathrm{~km}$. Thus, the effectively sampled area was 64,803 ha. The area occupied by the lynx was 25,067 ha.

\section{Discussion}

Iberian lynx population situation

Our results show that in the Doñana area, the total Iberian lynx population size is around 26 individuals older than a year, occupying 25,067 ha. Despite the methodological differences with the Palomares et al. (1991) study, where 45 individuals were reported, a decline in the number of lynxes since the 1980s can be seen.

A few years after the appearance of RHD during the early $1990 \mathrm{~s}$, the estimated rabbit population decrease was about 40\% (Villafuerte et al. 1994). At present, the wild rabbit is almost completely absent in $75 \%$ of the entire area (Guzmán et al. 2004). This rabbit population crash appears to be the principal cause of the lynx decline.

Approximately half of the Doñana lynx population lives in only a quarter of its distribution area, precisely where the best rabbit populations are located: along the northern National Park boundary and the western limits of the Natural Park (Guzmán et al. 2004).

This situation reveals a new spatial distribution of lynx in the Doñana area. In the 1980 s, approximately $80 \%$ of all lynx individuals were found inside the National Park boundaries, another $10 \%$ in the adjacent area, and the rest at some distance from it (Palomares et al. 1991). In this study, however, only less than a half of the remaining lynx individuals have been detected inside the National Park, and the species has almost completely disappeared from the southern third of the National Park. Only one photograph 
has been obtained in this area, of a female whose resident area (where it is regularly detected), is located $20 \mathrm{~km}$ away.

The theory states that given the current estimate obtained, the population is not genetically viable (Soulé 1980; Shaffer and Samson 1985). In such small and isolated populations, the loss of genetic variability is accelerated (Franklin 1980), and so makes them extremely fragile. In fact, a recent study indicated that all lynxes necropsied between 1998 and 2003 in the Doñana area presented some degree of immunosuppression (Peña et al. 2006) and membranous glomerulopathy, a progressive disease of immunological origin, was diagnosed in all but one of the animals (Jiménez et al. 2008). The authors postulate a possible genetic predisposition towards the disease, enhanced by inbreeding and a possible connection to an immune-mediated systemic disease.

\section{Applicability of camera-trap surveys}

The present study probably represents the largest survey effort ever applied in a camera-trapping study (543 camera traps; 16,290 trapping nights). As a result, practically all of the Doñana area's Iberian lynx population distribution area was surveyed in little more than 2 months.

The estimated average capture probability $(0.1115)$, and the estimated probabilities of missing an animal $\left(1-\mathrm{M}_{\mathrm{t}} / N<\right.$ 0.25 ) are similar to those obtained from other studies on the tiger (Karanth and Nichols 1998), jaguar (Kelly et al. 2008), and ocelot (Trolle and Kéry 2003).

Attractants are commonly used in capture-recapture population estimates, including carnivores (Trolle and Kéry 2003; Henschel and Ray 2003), deer (Curtis et al. 2009), and small mammals (Efford et al. 2005). However, some studies avoid the use of attractants because they can cause heterogeneity in the captures (Jacobson et al. 1997). The model selection algorithm identified $\mathrm{M}_{\mathrm{h}}$ as the most appropriate model, showing the existence of heterogeneity in capture probabilities between individuals given the social structure and unequal access to camera traps. In addition, based on our data, we can assume that the attractant used does not produce a significant differential effect neither on sex nor on age classes which would lead to changes in the estimates. Besides the effect of the possible variability between sexes, ages, or individuals is adequately "buffered" by applying the $\mathrm{M}_{\mathrm{h}}$ model of individual heterogeneity, which is known to be robust to violation of underlying model assumptions (Otis et al. 1978; Burnham and Overton 1979).

One of the assumptions of capture-recapture analysis is the absence of gaps in the study area that were not surveyed where any individual had zero probabilities of being captured (Karanth and Nichols 1998). Though in this study the entire area potentially used by Iberian lynx was surveyed, there exist areas that were not covered in the camera-trapping survey. These areas correspond with open areas (agricultural areas or without bush cover) or areas where rabbit is absent, that are rejected by lynxes and considered inadequate for the establishment of territories and that are used by dispersal individuals only (Palomares et al. 2000). Although the probability that a lynx territory could have existed inside these areas that were not surveyed is small, a disperser may have used them during the study. This fact could suppose a violation of the assumption and therefore could affect to the final estimation.

Our study shows that as with other carnivore species, photographic capture-recapture methods are applicable for estimating the abundance of Iberian lynx populations, as they are a fast, effective, and non-invasive method for establishing the status of these populations.

The deployment of remote cameras offers a helpful means to obtain additional information. Camera trapping makes it possible to establish the limits of the distribution area, to obtain information about the population sex ratio, and occasionally, to detect individuals with poor body condition or which are injured. This permits rapid response action for these individuals, if necessary.

With successive camera-trapping surveys, it would be possible to identify resident lynxes, i.e., those individuals detected within the same area over successive seasons and years (Hemker et al. 1984). This information is especially important in the case of the females, since monitoring resident females is the most reliable means for assessing the trend of a particular population (Karanth and Nichols 2002).

There also appears to be a potential for using long-term camera-trapping surveys to estimate additional population parameters such as survival, mortality, recruitment, and dispersal rates for Iberian lynx, by applying open capturerecapture models that are currently available (Seber 1982; Pollock et al. 1990; Lebreton et al. 1992).

Additionally, remote monitoring reduces adverse effects that may be caused by more invasive methods including complications due to capture, destructive marking techniques, and also reduces behavioural changes due to the capture or marking process (Heilbrun et al. 2006).

Considering our results, we recommend to conduct surveys of at least 1 month length (time necessary to stabilise the cumulative curve), with a density of one trap per 100 ha and covering the biggest area in consecutive stages to cover the whole study area.

\section{Conclusions}

As in the rest of its distribution area, the Iberian lynx in Doñana has suffered a decline leaving it in a critical 
situation, compromising its long-term survival, and placing it on the edge of extinction. Traditionally, the majority of the research studies, as well as conservation work undertaken on the Doñana population, have been carried out within the National Park boundaries (e.g., Ferreras et al. 1997; Lopez-Bao et al. 2008; Palomares et al. 1996, 2001), where higher levels of protection are present and disturbance to the species is minimal. However, given the new spatial distribution shown by the Doñana population, the survival of the species inexorably requires the implementation of adequate management beyond the National Park boundaries. And this implies continuous monitoring of its populations throughout its entire distribution area. This study has revealed the applicability of camera-trap surveys for making rapid, efficient, and non-invasive population estimates of the species. Establishing a repeated and consistent monitoring programme employing camera trapping could be an essential tool to detect population and/or range changes and for properly assessing the effectiveness of conservation investments targeting the Iberian lynx.

Acknowledgments The fieldwork and the economic support was possible through the collaboration between the Dirección General de Conservación de la Naturaleza (DGCONA-MIMAM, project "CensoDiagnóstico de las Poblaciones de Lince Ibérico en la Península Ibérica"), Organismo Autónomo de Parques Nacionales-Doñana, Parque Natural de Doñana, Delegación Provincial de Medioambiente de Huelva, and TRAGSA. We thank JA Blanco "J", E Virgós, JLTellería, and the anonymous reviewers for their constructive comments, and also Ramón Pérez de Ayala Giménez, Ricardo Balzola, John Muddeman, and Yolanda Cortés who helped with the translation.

\section{References}

Anon (1989) Plan Nacional de Coordinación de Doñana y su entorno. Consejería de obras Públicas y Transporte. Junta de Andalucía, Sevilla

Burnham KP, Overton WS (1979) Robust estimation of population size when capture probabilities vary among animals. Ecology 60:927-936

Cabrera A (1914) Fauna ibérica. Mamíferos. Museo Nacional de Ciencias Naturales, Madrid

Curtis PD, Boldgiv B, Mattison PM, Boulanger JR (2009) Estimating deer abundance in suburban areas with infrared-triggered cameras. Hum Wildl Conf 3:116-128

Cutler TL, Swann DE (1999) Using remote photography in wildlife ecology: a review. Wildl Soc Bul 27:571-581

Efford MG, Warburton B, Coleman MC, Barker RJ (2005) A field test of two methods for density estimation. Wildl Soc Bul 33:731-738

Ferreras P (2001) Landscape structure and asymmetrical inter-patch connectivity in a metapopulation of the endangered Iberian lynx. Biol Conserv 100:125-136

Ferreras P, Aldama J, Beltrán JF, Delibes M (1997) Spatial organization and land tenure system of the endangered Iberian lynx (Lynx pardinus), Temminck, 1824). J Zool 243:163-189

Franklin IR (1980) Evolutionary change in small populations. In: Soule ME, Wilcox BA (eds) Conservation biology, an evolutionary-ecological perspective. Sinauer, Sunderland, pp $135-149$
Garrote G, García FJ, Guzmán JN, Perez de Ayala C, Iglesias C, Pereira P, Robles F (2001) Aplicación de técnicas de autofotografía en trabajos de conservación de especies amenazadas. El caso del lince ibérico (Lynx pardinus). VI jornadas de la Sociedad Española de Conservación y Estudio de Mamíferos. Vitoria-Gasteiz

Gibbs JP (2000) Monitoring populations. In: Boitani L, Fuller TK (eds) Research techniques in animal ecology. Columbia University Press, New York, pp 213-252

Graells MP (1897) Fauna mastozoologica ibérica. Mem Rea Aca Ciencias XVII. Madrid

Guzmán JN, García FJ, Garrote G, Pérez de Ayala R, Iglesias C (2004) El lince ibérico (Lynx pardinus) en España y Portugal. Censo diagnóstico de sus poblaciones. Dirección General para la Biodiversidad. Madrid

Heilbrun RD, Silvy NJ, Peterson MJ, Tewes ME (2006) Estimating bobcat abundance using automatically triggered cameras. Wildl Soc Bul 34:69-73

Hemker TP, Lindzey FG, Ackerman BB (1984) Population characteristics and movenments patterns of cougars in southern Utah. J Wildl Manag 48:1275-1284

Henschel P, Ray J (2003) Leopards in African rainforests: survey and monitoring techniques. WCS Global Carnivore Program. Wildlife Conservation Society

IUCN (2002) 2002 IUCN red list of threatened animals. IUCN, Gland and Cambridge

IUCN (2007) 2007 IUCN red list of threatened animals. IUCN, Gland and Cambridge

Jackson RM, Roe JD, Wangchuk R, Hunter DO (2006) Estimating snow leopard population abundance using photography and capture-recapture techniques. Wildl Soc Bul 34:772-781

Jacobson HA, Kroll JC, Browning RW, Koerth BH, Conway MH (1997) Infrared-triggered cameras for censusing white-tailed deer. Wildl Soc Bul 25:547-556

Jiménez MA, Sánchez B, Pérez Alenza MD, García P, López JV, Rodriguez A, Munóz A, Martínez F, Vargas A, Peña L (2008) Membranous glomerulonephritis in the Iberian lynx (Lynx pardinus). Vet Immunol Immunopathol 121:34-43

Karanth KU, Nichols JD (1998) Estimation of tiger densities in India using photographic captures and recaptures. Ecology 79:2852-2862

Karanth KU, Nichols JD (eds) (2002) Monitoring tigers and their prey: a manual for researchers, managers and conservationists in tropical Asia. Centre for Wildlife Studies, India

Kelly MJ, Noss AJ, Arispe L, Di Bitetti M, De Angelo CD, Paviolo A, Di Blanco YE, Maffei L (2008) Estimating puma densities from remote cameras across three study sites: Bolivia, Argentina, and Belize. J Mammal 89:408-418

Lancia RA, Nichols JD, Pollock KH (1994) Estimating the number of animals in wildlife populations. In: Bookhout TA (ed) Research and management techniques for wildlife and habitats. The Wildlife Society, Bethesda, pp 215-253

Lebreton JD, Brunham KP, Clobert J, Anderson DR (1992) Modeling survival and testing biological hypotheses using marked animals: a unified approach with case studies. Ecol Monogr 62:67-118

Lopez-Bao JV, Rodriguez A, Palomares F (2008) Behavioural response of a trophic specialist, the Iberian lynx, to supplementary food: patterns of food use and implications for conservation. Biol Conserv 141:1857-1867

Mitchell-Jones AJ, Amori G, Bogdanowicz W, Krystufek B, Reijnders PJH, Spitzenberger F, Stubbe J, Thissen JBM, Vohralik V, Zima J (1999) The atlas of European mammals. T. and A. D. Poyser Ltd./Societas Europaea Mammalogica, London

Murray DL, Fuller MR (2000) A critical review of the effects of marking on the biology of vertebrates. In: Boitani L, Fuller TK (eds) Research techniques in animal ecology. Columbia University Press, New York, pp 15-64 
Otis DL, Burnham G, White C, Anderson DR (1978) Statistical inference from capture data on closed animal populations. Wildl Monogr 62:1-135

Palomares F, Rodriguez A, Laffite R, Delibes M (1991) The status and distribution of the Iberian Lynx Felis pardina (Temminck) in Coto de Doñana, SW Spain. Biol Conserv 57:159-169

Palomares F, Ferreras P, Fedriani JM, Delibes M (1996) Spatial relationships between Iberian lynx and other carnivores in an area of south-western Spain. J App Ecol 33:5-13

Palomares F, Delibes M, Ferreras P, Fedriani JM, Calzada J, Revilla E (2000) Iberian lynx in a fragmented landscape: predispersal, dispersal, and postdispersal habitats. Cons Biol Vol 14(3):809-818

Palomares F, Delibes M, Revilla E, Calzada J, Fedriani JM (2001) Spatial ecology of Iberian lynx and abundance of European rabbits in southwester Spain. Wildl Monogr 148:1-35

Peña L, García P, Jiménez MA, Benito A, Pérez Alenza MD, Sánchez B (2006) Histopathological and immunohistochemical findings in lymphoid tissues of the endangered Iberian lynx (Lynx pardinus). Comp Immunol Microbial Infect Dis 29:114-126

Peterson MN, Lopez RR, Frank PA, Peterson MJ, Silvy NJ (2003) Evaluating capture methods for urban white-tailed deer. Wildl Soc Bul 31:1176-1187

Pollock KH, Nichols JD, Brownie C, Hines JE (1990) Statistical inference for capture-recapture experiments. Wildl Monogr 107:1-97

Rau JR, Beltrán JF, Delibes M (1985) Can the increase of fox density explain the decrease in lynx numbers at Doñana? Rev Ecol (Terre vie) $40: 145-150$

Rexstad E, Burnham KP (1991) User's guide for interactive program CAPTURE. Abundance estimation of closed populations. Colorado State University, Colorado

Rivas-Martínez S (1987) Memoria del Mapa de Series de Vegetación de España. 1: 400000. ICONA, Madrid

Rodríguez A, Delibes M (1992) Current range and status of the Iberian lynx Felis pardina Temminck, 1824 in Spain. Biol Conserv 61:189-196
Rodríguez A, Delibes M (2003) Population fragmentation and extinction in the Iberian lynx. Biol Conserv 109:321-331

Seber GAF (1982) The estimation of animal abundance and related parameters, 2nd edn. MacMillan, New York

Shaffer ML, Samson FB (1985) Population size and extintion: a note on determining critical population sizes. Amer Nat 125:144-152

Silver SC, Ostr LET, Marsh LK, Maffei L, Noss AJ, Kelly MJ, Wallace RB, Gomez H, Ayala G (2004) The use of camera traps for estimating jaguar Panthera onca abundance and density using capture/recapture analysis. Oryx 38:148-154

Simón MA (2008) Currente status of Iberian lynx in Andalusia. Proceedings of the III Iberian lynx International Seminar. Andalusia Government, IUCN/SC Cats Specialist Group

Soisalo MS, Cavalcanti SMC (2006) Estimating the density of a jaguar population in the Brazilian Pantanal using camera-traps and capture-recapture sampling in combination with GPS radiotelemetry. Biol Conserv 129:487-496

Soulé ME (1980) Thresholds for survival: maintaining fitness and evolutionary potential. In: Soulé ME, Wilcox BA (eds) Conservation biology: an evolutionary-ecological perspective. Sinauer Associates, Sunderland, pp 151-169

Trolle M, Kéry M (2003) Estimation of ocelot density in the pantanal using capture-recapture analysis of camera-trapping data. J Mamm 84:607-614

Valverde JA (1963) Información sobre el lince en España. Min Agric Bol Tec, Ser Cinegética, 1

Villafuerte R, Calvete C, Gortázar C, Moreno S (1994) First epizooty of rabbit haemorragic disease on free living populations at Doñana National Park (SW Spain). J Wildl Dis 30:176-179

White GC, Burnham KP (1999) Program MARK: survival estimation from populations of marked animals. Bird Study 46:120-138

Zielinski WJ, Kucera TE (1995) American Marten, Fisher, Lynx, and Wolverine: survey methods for their detection. USDA Forest Service General Technical Report PSW GTR-157 